\title{
STUDY ON STABILITY CONTROL OF COAL MINE TUNNEL EXCAVATED IN WEAK ROCK MASS IN INDONESIA
}

\author{
Phanthoudeth Pongpanya ${ }^{1}$, Takashi Sasaoka ${ }^{2}$, Hideki Shimada ${ }^{2}$, Vongsavanh Soysouvanh ${ }^{2}$ \\ ${ }^{1}$ Department of Mining Engineering, Faculty of Engineering \\ National University of Laos, Vientiane, Lao PDR \\ ${ }^{2}$ Department of Earth Resources Engineering, Faculty of Engineering \\ Kyushu University, Fukuoka, Japan
}

\begin{abstract}
This paper focuses on the stability analysis and support design of the coal mine tunnel excavated in weak rock mass in an Indonesian underground coal mine through numerical simulations using the FLAC3D software. The PT Gerbang Daya Mandiri (GDM) coal mine situated in Indonesia was selected as a mine site in this study. According to the results of a series of numerical simulations, the stability of the mine tunnel decreases by increasing the depth and stress ratio. Ground control problems, for example falling roof, sidewall collapse, and floor heave are expected unless an appropriate support system is anticipated. Three support systems, including friction rockbolt, steel arch, and shotcrete are discussed as methods to stabilize the roof and sidewalls of the mine tunnel. From the simulated results, the steel arch is considered to be the most effective support method when compared with other support systems. The steel arch which is installed with closer space and larger crosssection delivers a better stability control to the roof and sidewalls of the mine tunnel. Although the stability of the roof and sidewalls of the mine tunnel can be maintained effectively by the steel arch support, the occurrence of floor heave is expected when the mining depth is increased. To control the floor stability of the mine tunnel, three techniques by applying cablebolt, invert-arch floor, and grooving method are therefore investigated and discussed. Based on simulated results, the heaving of the floor is well controlled after the cablebolt, invert-arch floor, and grooving methods are applied. Nevertheless, it is found that controlling the floor heave by cablebolt support could be the most suitable method comparing with other support systems in terms of the installation process, providing flat and safe working conditions of the floor, and economy. Additionally, the cablebolt with closer row space and longer length works more effectively to control the heaving problem of the floor.
\end{abstract}

Keywords-Mine Tunnel Stability, Support Design, FLAC3D, Weak Rock

\section{INTRODUCTION}

Coal is one of the world's most important sources of energy which has been widely used as fuel in many industrial sectors such as electricity generation, cement and steel production, and other manufacturing activities. The coal production of Indonesia has increased significantly in the past years (Fig. 1). Indonesia exports the coal mostly to China and India, accounted for 70 to $80 \%$ of the total coal production, while the remaining is consumed in domestic markets [1]. The coal production in Indonesia is mainly from the surface mining method. Recently, many surface mines have been stopped in their operations due to an increase in stripping ratio [2-5]. In addition, there are many problems concerning the environmental impacts and protection challenges to expand the current surface mines and exploit the new ones, especially where the coal seams are located beneath agricultural areas, protected forests, and man-made structures. Therefore, to meet the increased demands of the coal production of the country, some underground coal mines have to be developed.

In Indonesia, the coal measure strata consist of sedimentary rocks such as sandstone, claystone, siltstone, shale, and mudstone. Their mechanical properties are generally weak and deteriorated due to water. Results of the uniaxial compressive strength (UCS) test indicated that the strengths of rocks in Indonesian coal mines are much lower than that of coal mines in other countries (Fig. 2). The UCS value of coal measure rocks is mostly less than $25 \mathrm{MPa}$ [2-7]. The rocks of Indonesian coal mines can be classified into weak and low strength rocks $[8,9]$. 


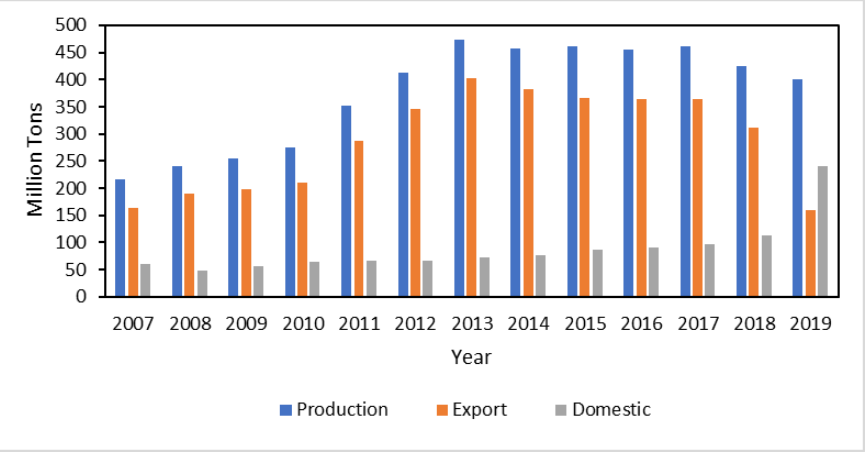

Fig. 1. History of annual coal production, export, and domestic consumption in Indonesia

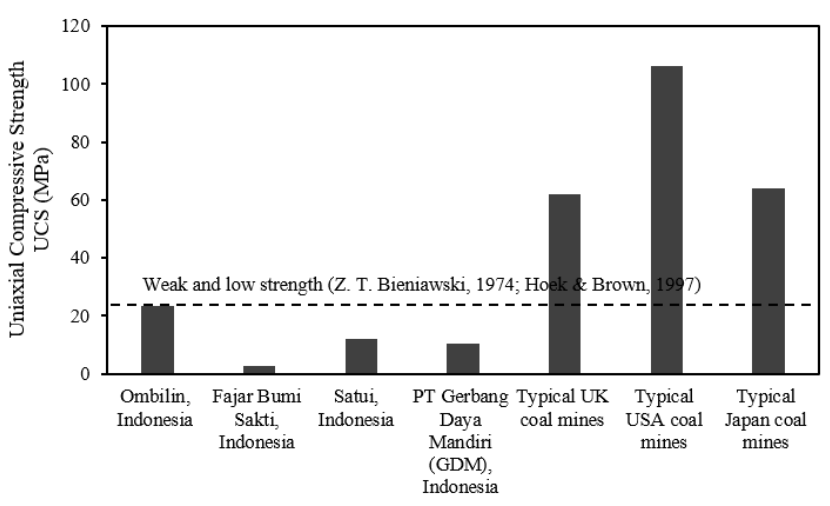

Fig. 2. Comparison of uniaxial compressive strengths of coal measure rocks in Indonesia, UK, USA, and Japan

Due to the weak geological conditions of coal measure strata, the instability of a mine tunnel becomes the major ground control problem during the development of an underground coal mine in Indonesia [2-4]. In recent years, several attempts have been made to develop underground mines from the final highwall of old surface mines, for example, the Satui coal mine in South Kalimantan and Indominco coal mine in East Kalimantan. Satui underground mine was commenced in 2002. This coal mine adopted an Australian roof bolt support system for the development of the mine tunnel. Unfortunately, this underground coal mine was abandoned in 2005 due to a fatal accident of a falling roof in the mine tunnel. Two miners were killed, and the other two were injured. The accident occurred due to inadequate roof supports in weak ground conditions [3, 10]. Indominco coal mine started the trial underground operation in 2009. When this underground mine was proposed, it was recognized that the ground control issue that happened at the Satui trial underground mine needs to be solved. Even though rock bolting is well established as support technology in Australian coal mines, but this technique alone is not capable to maintain mine tunnel stability in Indonesia due to weak ground conditions coupled with the lack of local experience. Therefore, a new immediate roof classification system called
Coal Mine Roof Rating (CMRR) was adopted for a roof bolting design in this trial mine. According to the monitoring result of ground behavior, the large displacement of the roof was recognized, and it increased constantly within the elapsed time after the mine tunnel was excavated. The phenomenon has indicated that the rock bolting system would control the roof only for a short period of time, but it would not work effectively after a long period even additional roof bolts are installed [4]. However, although a trial underground mine at Indominco coal mine completely recovered the reserves without any fatal accident, it could not go further for full mining operations at deeper levels because too much cost is required for support installation. As a result, this underground coal mine was eventually abandoned.

According to the ground control problems that occurred at underground coal mines in Indonesia, it can be said that the guidelines of mine tunnel support design used in Australia or other countries cannot be directly applied in Indonesia due to the rocks are very weak. Because the appropriate design guidelines of mine tunnel support are lacking, the experiences and expertise of local mining engineers concerning underground mining are restrained. As a result, severe ground control problems have occurred regularly, and some underground operations have failed.

To ensure the success of future underground coal mines in Indonesia, the appropriate design guidelines of the mine tunnel support that suit geological conditions in Indonesia are therefore required. This paper discusses the stability analysis and support design of the coal mine tunnel excavated in weak rock mass by means of numerical simulation using the finite difference code FLAC3D software. The PT Gerbang Daya Mandiri (GDM) underground coal mine in Indonesia, where the rocks are weak, was selected as a research mine site in the study.

\section{Site Conditions of GDM Underground CoAl Mine}

GDM coal mine is one of the underground coal mines which has been being operated in Indonesia. This underground coal mine is located in Samarinda City, East Kalimantan, Indonesia, and it is currently in the process of constructing the mine tunnels. Figure 3 illustrates the location map of the coal mine. The recoverable sub-bituminous coal of the GDM coal mine is approximately 29.2 million tons. Annually, the extraction of 1 million tons of the coal is planned for the GDM coal mine by using the longwall mining technique. The layout of the coal panels of the GDM coal mine is presented in Figure 4. Two mine tunnels namely North and South Portal, are being excavated by using the road header machine to access the coal seams (Fig. 5). The tunnel excavation commenced from the final highwall of the old surface mine. The total height of the overburden is about $15 \mathrm{~m}$ above a current excavation face. The tunnels are designed using a semi-circular shape with $5 \mathrm{~m}$ width and $3 \mathrm{~m}$ height. The tunnels are stable in the current situation at the shallow depth with the occurrence of some cracks and rock mass 


\section{International Journal of Engineering Applied Sciences and Technology, 2021 \\ Vol. 6, Issue 4, ISSN No. 2455-2143, Pages 145-159 \\ Published Online August 2021 in IJEAST (http://www.ijeast.com)}

deformations along the roof and sidewalls. These rock failures are well supported by the steel arch support of $1 \mathrm{~m}$ spacing.

The geological map of the GDM underground coal mine is given in Figure 6. The GDM underground coal mine is located within the Kutai Basin formed in the Tertiary geological period. The major coal-bearing formations in the Kutai Basin are Balikpapan and Pulau Balang Formations. Balikpapan formation consists of coal, sandstone, mudstone, siltstone, and coaly shale. Whilst, Pulau Balang formation mainly consists of mudstone, sandstone, siltstone, coal, and coaly shale.

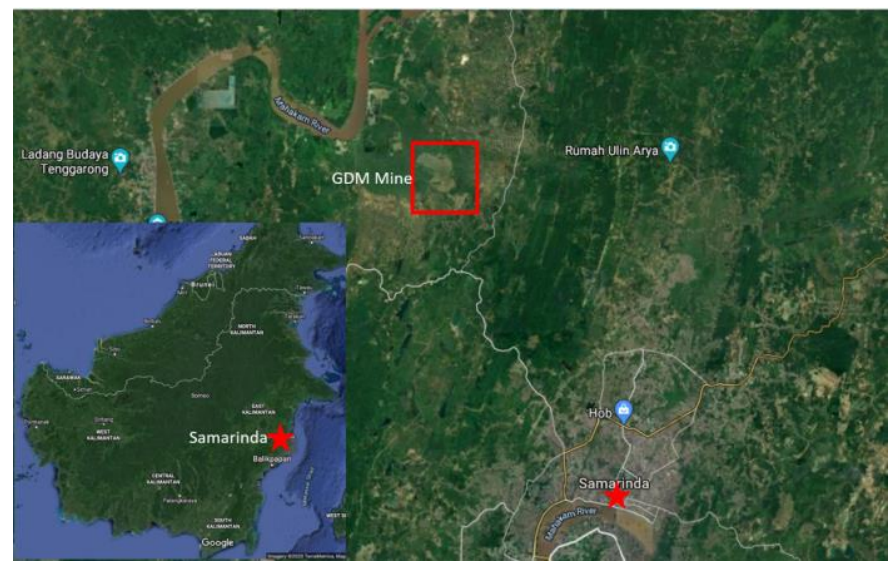

Fig. 3. Location map of GDM underground coal mine

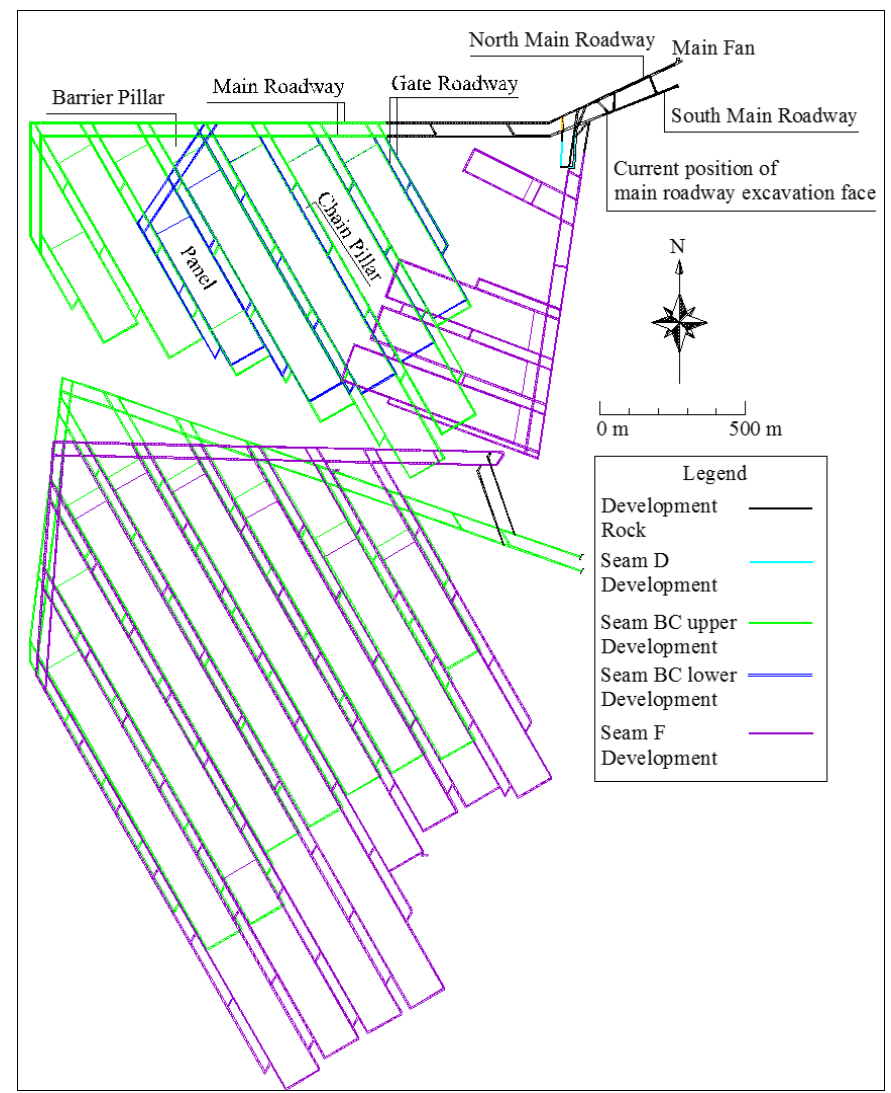

Fig. 4. Mine layout of GDM underground coal mine

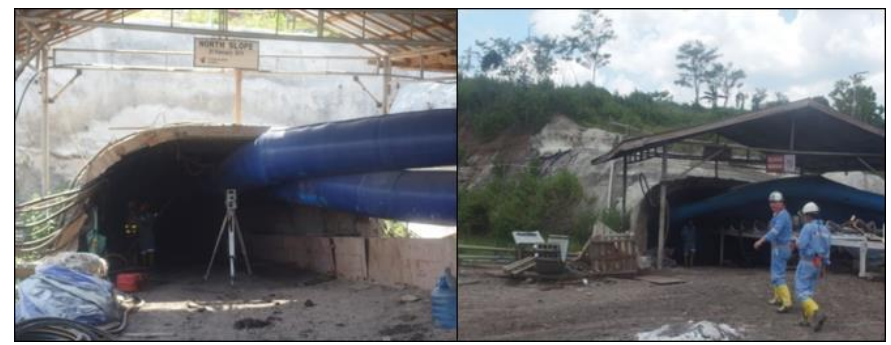

Fig. 5. South Portal of GDM underground coal mine

In the GDM coal mine, the geological structure is generally a simple monocline structure, while the fault was not found within the area. The GDM coal consists of several seams which are part of the Kutai Basin with the dip ranging from $3^{\circ}$ to $13^{\circ}$, and the coal seam thickness varies from $0.15 \mathrm{~m}$ to $9.8 \mathrm{~m}$. The typical stratigraphy of the GDM underground mine is illustrated in Figure 7. The major mineable seam for underground mining is found in Seam BC. The thickness of Seam BC varies from $3.31 \mathrm{~m}$ to $9.80 \mathrm{~m}$. Claystone and sandstone are rock layers that separate the coal seams. However, claystone is a dominant rock unit.

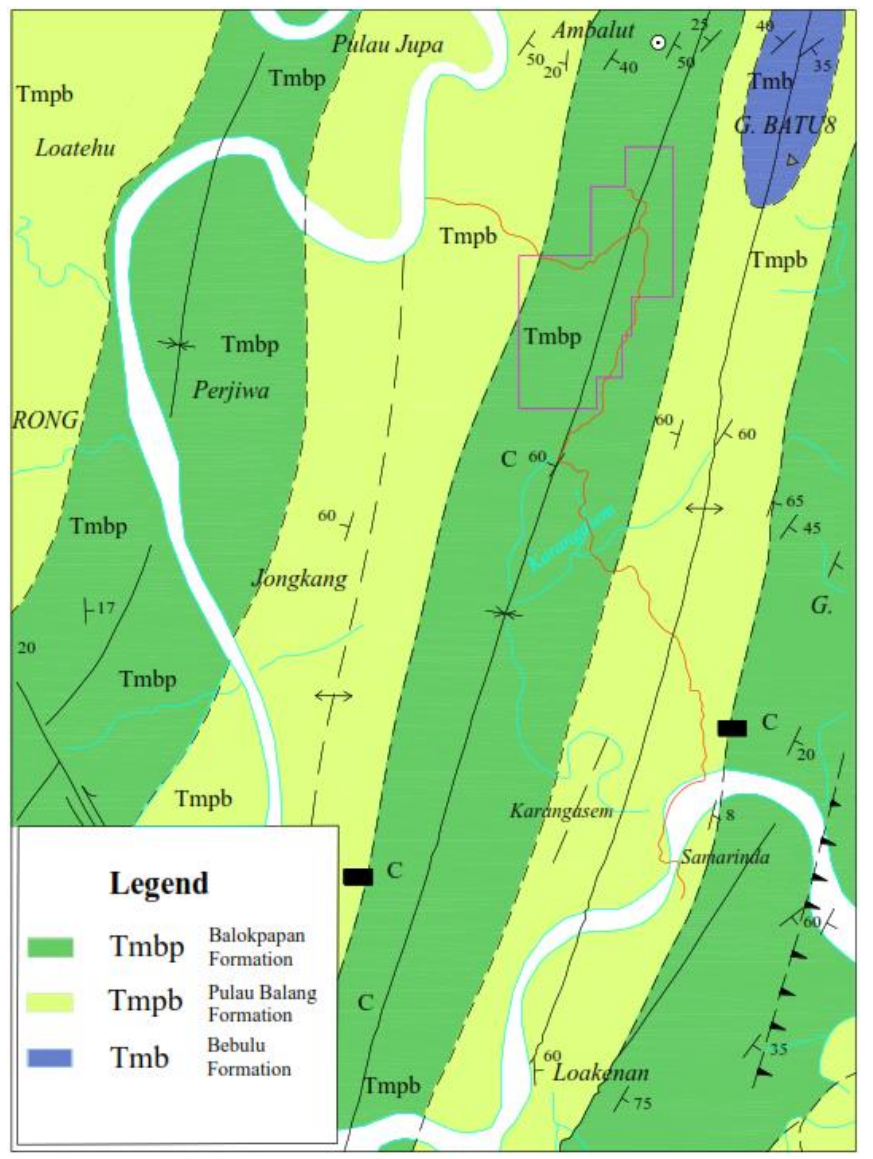




\section{International Journal of Engineering Applied Sciences and Technology, 2021 \\ Vol. 6, Issue 4, ISSN No. 2455-2143, Pages 145-159 \\ Published Online August 2021 in IJEAST (http://www.ijeast.com)}

Fig. 6. Geological map of GDM underground coal mine

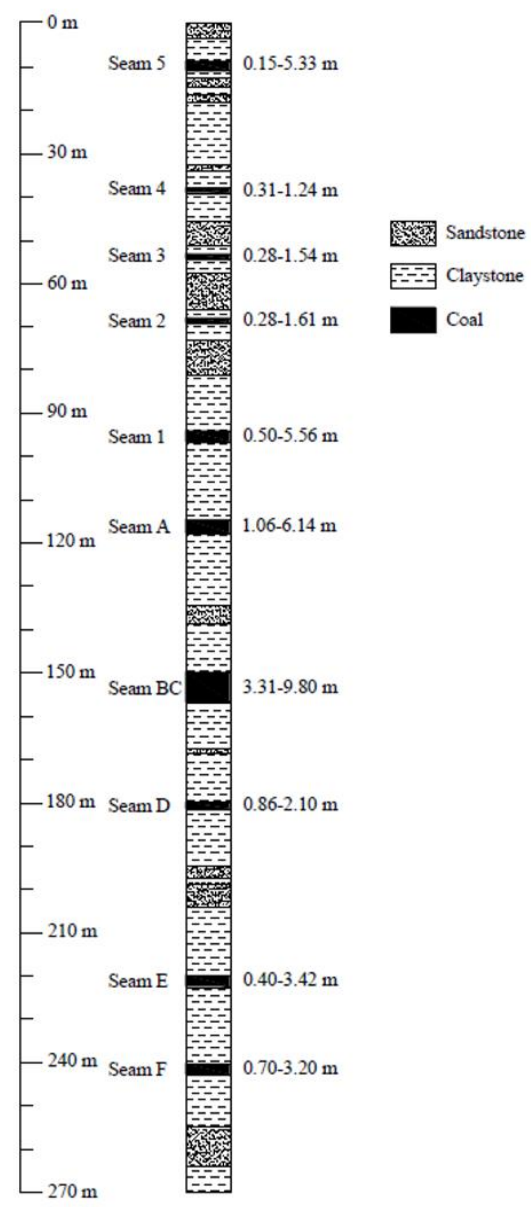

Fig. 7. Stratigraphic column of GDM underground coal mine

Figure 8 illustrates the relationship between uniaxial compressive strength and young's modulus of rock and coal. These results were obtained from the Laboratory of Geomechanics and Mine Equipment, Institute of Technology of Bandung, Indonesia. Coal and rock samples were collected from boreholes at different depths. Based on the laboratory test results, the rock and coal in this underground mine are classified into weak and low strength rocks $[8,9]$.

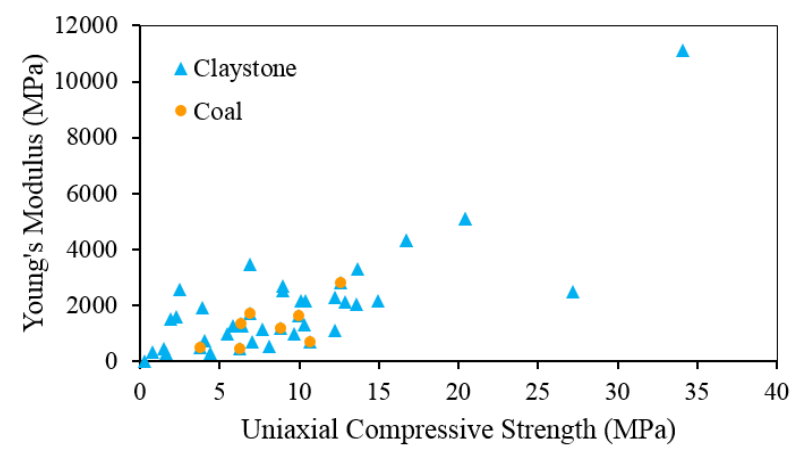

Fig. 8. Relationship between uniaxial compressive strength and young's modulus of claystone and coal of GDM coal mine

In the GDM coal mine, as the mine tunnel has to be excavated at the deep depth to reach the targeted coal seam, and the coal measure rocks are weak; some ground control problems of roof fall, sidewall collapses, and floor heave can be expected. Excavation of the mine tunnel at the deep area challenges geotechnical engineers for designing the rock support system. Under-design of support system can lead to instability of the mine tunnel, whereas over-design will result in unnecessary high excavation costs. Therefore, the appropriate design of support system is of particular necessity for this underground coal mine. In this paper, the stability of the mine tunnel is numerically studied, and the appropriate support systems are consequently proposed for GDM underground coal mine.

\section{DESCRIPTION OF NUMERICAL MODEL}

A numerical 3D finite difference code software (FLAC3D) was used to study the stability of the mine tunnel [11]. Several numerical models were created under various overburden depths such as $50 \mathrm{~m}, 100 \mathrm{~m}, 200 \mathrm{~m}$, and $300 \mathrm{~m}$. An example of the model at $200 \mathrm{~m}$ depth is described in Figure 9.

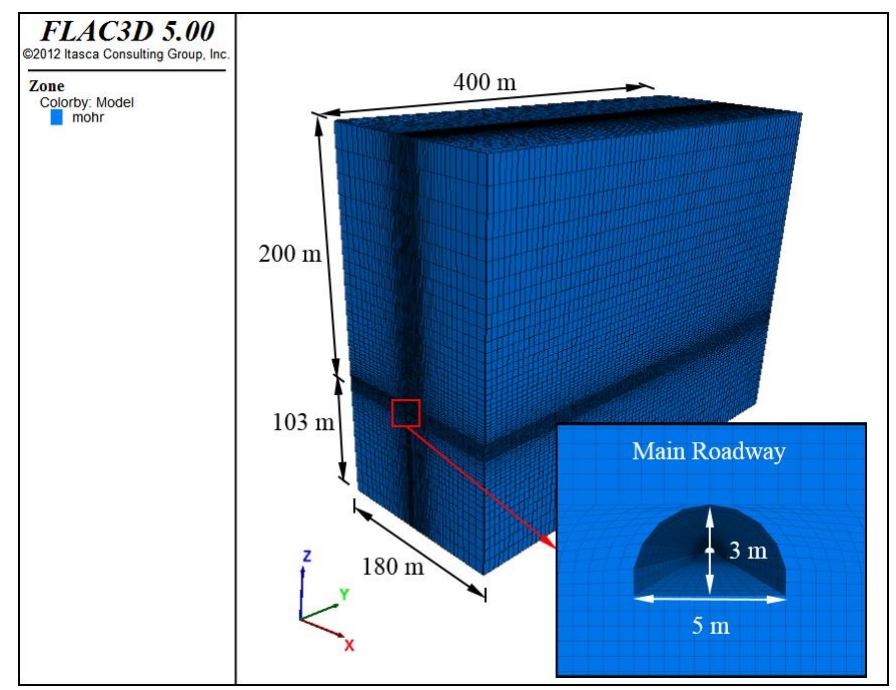




\section{International Journal of Engineering Applied Sciences and Technology, 2021 \\ Vol. 6, Issue 4, ISSN No. 2455-2143, Pages 145-159 \\ Published Online August 2021 in IJEAST (http://www.ijeast.com)}

Fig. 9. Geometries of numerical model under $200 \mathrm{~m}$ overburden depth

The width of the model is $180 \mathrm{~m}$, the length is $400 \mathrm{~m}$, and the height is $303 \mathrm{~m}$. The size of the mine tunnel excavation was modeled conforming to the design of the mine as $5 \mathrm{~m}$ in width and $3 \mathrm{~m}$ in height. The excavation length of $250 \mathrm{~m}$ was considered in the simulations. The bottom of the model was fixed in the vertical direction, the sides were fixed in the horizontal direction, while the surface was free in all directions. As claystone is the main rock type in the GDM coal mine, the overburden and underburden were therefore modeled as homogenous claystone layers. To obtain the most precise result of the simulation, the lateral and vertical meshes were intentionally made finer around the excavation area than the remaining meshes. Due to the field measurement data of in-situ stresses at the mine site have been unknown, three horizontal to vertical stress ratios $(\mathrm{k}=1.0,1.5$, and 2.0) were assumed in the simulations. The constitutive model of elastoplastic Mohr-Coulomb was used in the analyses. Table 1 presents the mechanical properties of claystone used in the numerical simulations.

Table -1 Mechanical properties of rock mass used in simulations

\begin{tabular}{|c|c|}
\hline Parameter & Claystone \\
\hline Uniaxial compressive strength (MPa) & 10.49 \\
\hline Density $(\mathrm{kg} / \mathrm{m3})$ & 2140 \\
\hline Young's modulus (MPa) & 2325 \\
\hline Poisson's ratio & 0.27 \\
\hline Friction angle $\left({ }^{\circ}\right)$ & 37.5 \\
\hline Cohesion (MPa) & 0.56 \\
\hline
\end{tabular}

\section{RESULT AND DISCUSSION}

\section{A. Stability of mine tunnel under various overburden} depths and stress ratios

Failure zones of unsupported mine tunnels excavated at various depths under different stress ratios are presented in Figure 10. It is revealed that the overburden depth and high stress ratio have significant impacts on the stability of the mine tunnel. The failure zone considerably increased with increasing the overburden depth and stress ratio. At a deeper depth and under a higher stress ratio, more severe failures occurred, especially in the roof and floor. This is because of an increase of in-situ stress resulted from increasing the thickness of the overburden and stress ratio. Under this condition, serious roof fall, sidewall collapse, and floor heave of the mine tunnel can be expected. To prevent these ground control problems, the GDM coal mine must select the appropriate support system for the mine tunnel. The support designs of the roof, sidewalls, and floor were studied and discussed in the following sections.

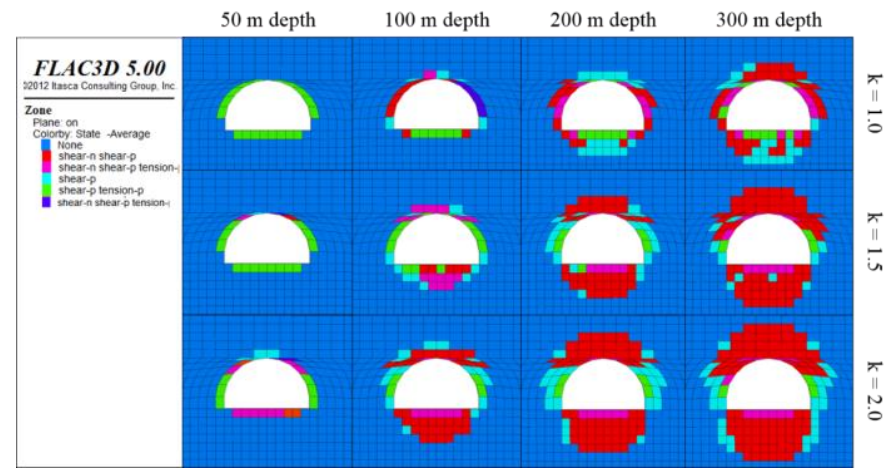

Fig. 10. Failure zone of unsupported mine tunnel under various overburden depths and stress ratios

\section{$B$. Support design of mine tunnel in roof and sidewalls}

Several types of supports have been used to stabilize the underground tunnels for decades, such as bolting supports, steel arch, and shotcrete [12-15]. In this paper, three support systems such as friction rockbolt, steel arch, and shotcrete were simulated in order to investigate their effects for controlling the stability of the mine tunnel at the GDM underground coal mine (Fig. 11).

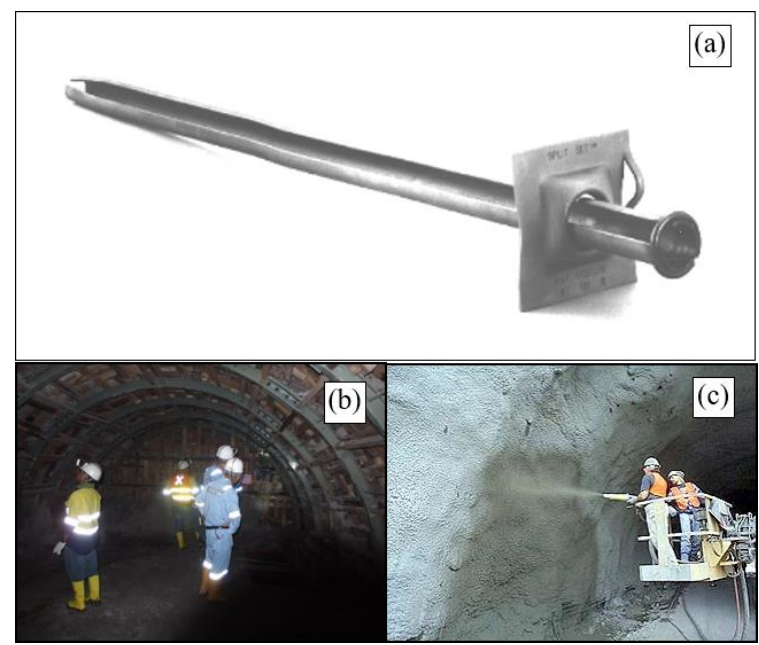

Fig. 11. Support systems for roof and sidewalls of mine tunnel (a) Friction rockbolt (b) Steel arch (c) shotcrete

Friction rockbolt is beneficial to enhance the mechanical properties of the rock by tightening the loose blocks of the rock near the excavation surface. It helps the rock to support itself and prevents the fall of roof and sidewalls that may create unsafe working conditions. Steel arch does not interact with the rock mass in the same way as rockbolt. Generally, this support can only respond to loads imposed on it by the inward movement of the rock. The shotcrete is a very effective support medium and is used to prevent small pieces of rocks from unraveling from the excavation surface. It helps to retain the 


\section{International Journal of Engineering Applied Sciences and Technology, 2021 \\ Vol. 6, Issue 4, ISSN No. 2455-2143, Pages 145-159 \\ Published Online August 2021 in IJEAST (http://www.ijeast.com)}

interlocking and self-supporting characteristics of the rock mass, and also helps to block the pathway of the water that can flow into the underground opening by sealing the joints in the rock mass. The mechanical properties of each support type used in the analyses are given in Tables 2-4. Ten friction rockbolts with $1 \mathrm{~m}$ row spacing (Fig. 12), steel arch of $1 \mathrm{~m}$ space, and shotcrete of $10 \mathrm{~cm}$ thickness, were considered in the simulations. Figure 13 illustrates a comparison of failure zones around the mine tunnel after three support systems were installed. From the results, the improvement of the mine tunnel stability was observed comparing with the tunnel without support. A significant stability improvement was obtained when the steel arch and shotcrete were applied. In contrast, the least improvement was achieved as large failure zones still occurred although the friction rockbolt support was used. It was due to the difficulty of the friction rockbolt to have sufficient anchorage in the weak rock mass. It can be said that the use of friction rockbolt as the main support system is not suitable to maintain the mine tunnel in GDM underground coal mine. Therefore, the tunnel support has to be either in the form of a steel arch or shotcrete.

Table -2 Mechanical properties of friction rockbolt used in simulations

\begin{tabular}{|c|c|}
\hline Parameter & Value \\
\hline Length (m) & 2.5 \\
\hline Diameter (mm) & 46 \\
\hline Typical tensile strength (kN) & 178 \\
\hline Young's modulus (GPa) & 200 \\
\hline Poisson's ratio & $\mathbf{0 . 2 5}$ \\
\hline Yield strength (MPa) & $\mathbf{5 8 8}$ \\
\hline
\end{tabular}

Table -3 Mechanical properties of steel arch (JIS 3010) used in simulations

\begin{tabular}{|c|c|}
\hline Parameter & Value \\
\hline Dimension $(\mathbf{m m})$ & $\mathbf{9 5 \times 1 1 5}$ \\
\hline Cross section area $\left(\mathrm{cm}^{\mathbf{2}}\right)$ & $\mathbf{3 6 . 5 1}$ \\
\hline Young's modulus $(\mathbf{G P a})$ & $\mathbf{2 0 0}$ \\
\hline Poisson's ratio & $\mathbf{0 . 3 0}$ \\
\hline Yield strength, SS540 $(\mathrm{MPa})$ & $\mathbf{5 5 1}$ \\
\hline
\end{tabular}

Table -4 Mechanical properties of shotcrete used in simulations

\begin{tabular}{|c|c|}
\hline Parameter & Value \\
\hline Uniaxial compressive strength (MPa) & 35 \\
\hline Young's modulus (GPa) & 21 \\
\hline Poisson's ratio & 0.15 \\
\hline Cohesion (MPa) & 10 \\
\hline Friction angle $\left({ }^{\circ}\right)$ & 30 \\
\hline
\end{tabular}

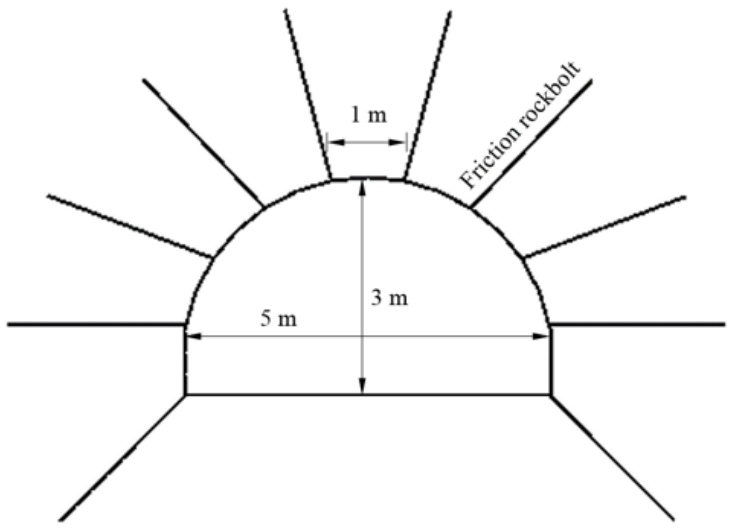

Fig. 12. Friction rockbolt pattern of mine tunnel

Based on simulated results presented in Figure 13, a big difference in failure zone was not observed between the tunnels supported by steel arch and shotcrete. However, the shotcrete produced a smaller failure zone than that in the case of the steel arch. This is due to the shotcrete possesses a higher resistance to the compressive stress than that of the steel arch. Even though the shotcrete provided a better stability condition of the mine tunnel, since the mine tunnel was excavated in weak rocks, the shotcrete should be thus installed immediately behind the tunnel advance, and this makes the placement of a full shotcrete lining during the excavation is impractical due to time-consuming of the shotcrete hardening. In addition, the installation cost of the shotcrete in Indonesian underground mines is much higher than that of the steel arch as summarized in Table 5 [16]. Hence, the remaining option for the support of the mine tunnel in the GDM coal mine is using the steel arch. The steel arch is considered as the most appropriate support to be used not only because it has good stability control and a fast installation process, but it has also a justifiable cost. 


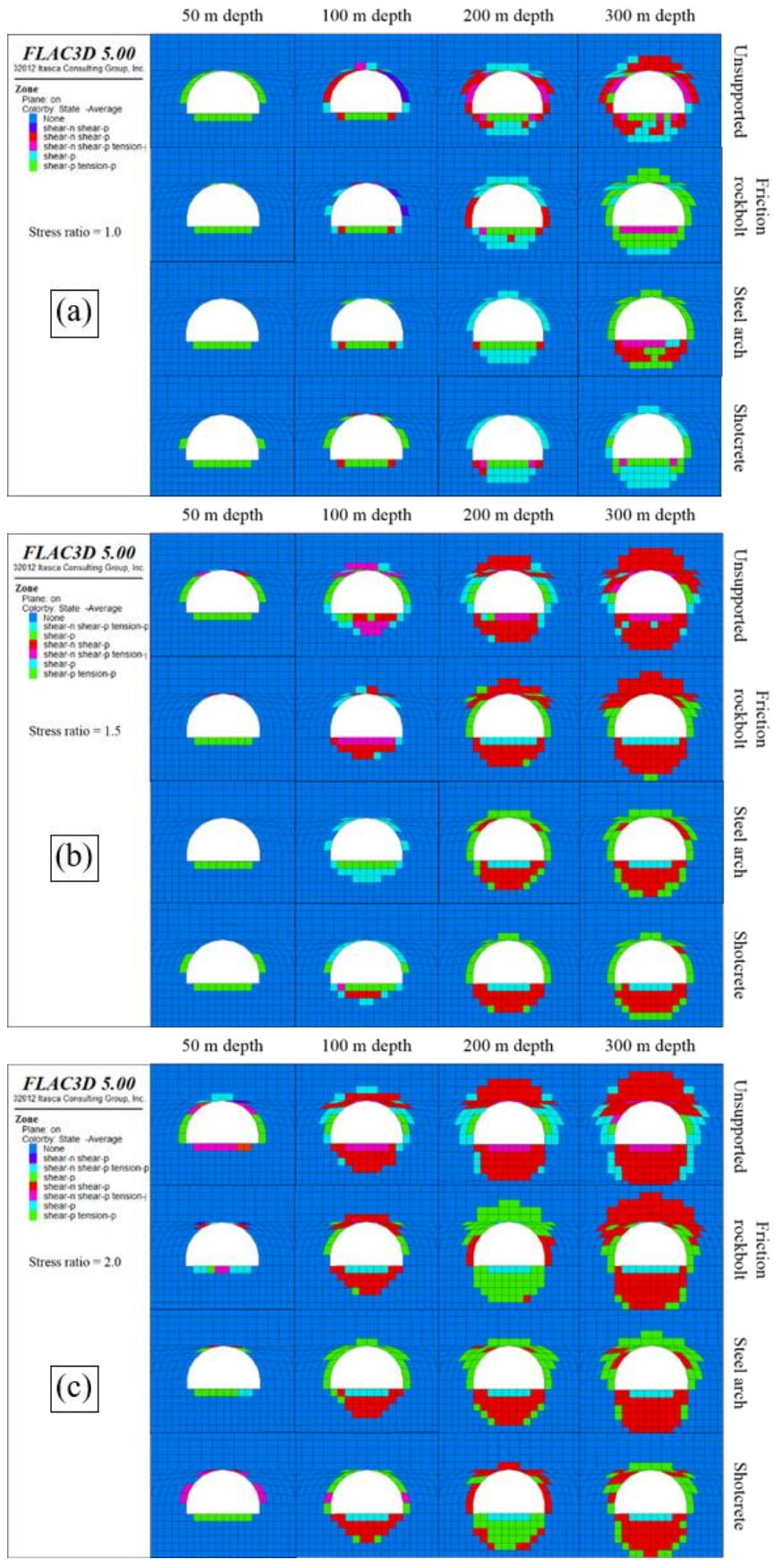

Fig. 13. Failure zone of mine tunnel after installation of friction rockbolt, steel arch, and shotcrete (a) $\mathrm{k}=1.0$ (b) $\mathrm{k}=1.5$ (c) $\mathrm{k}=2.0$

Table -5 Price in $1 \mathrm{~m}$ length of support installation in Indonesian underground mine

\begin{tabular}{|c|c|}
\hline Support type & Price (USD) \\
\hline Friction rockbolt & 853 \\
\hline Steel arch & 2000 \\
\hline Shotcrete & 2368 \\
\hline
\end{tabular}

Although the friction rockbolt and shotcrete are inappropriate to be applied as the main support system for the mine tunnel, they still can be used together with the steel arch as auxiliary support where a higher support capacity is needed. The friction rockbolt or shotcrete will be applied after the steel arch is installed. In order to understand the effect of the combined supporting system on the mine tunnel stability, the application of steel arch combining with friction rockbolt and shotcrete was investigated and discussed in this section. The steel arch space of $1 \mathrm{~m}$, the rockbolt row space of $1 \mathrm{~m}$, and the shotcrete thickness of $10 \mathrm{~cm}$, were fixed in the simulations. Figure 14 compares the failure conditions of the tunnel after the steel arch, steel arch with friction rockbolt, and steel arch with shotcrete were applied. Compared with the tunnel supported by steel arch only, the failure zones of the tunnel supported by steel arch combining with rockbolt and shotcrete decreased apparently. This proves that the use of rockbolt and shotcrete as auxiliary support in combination with the steel arch can improve the stability of the mine tunnel. Nevertheless, due to the limitation of the rockbolt to have a sufficient anchorage in the weak rock mass, it did not help the steel arch to maintain the tunnel as much as the shotcrete did, as a result, a larger failure zone occurred. Under all depths and stress ratios, the smallest failure zone occurred when the steel arch support was used together with shotcrete. This was because the shotcrete became part of the support system. It improved the load-bearing capacity of the steel arch as it helped to retain the interlocking and self-supporting characteristics of the rock mass. The combined supporting system of steel arch and shotcrete could respond to loads imposed on them more effectively. As a consequence, a smaller failure zone occurred. From an economical point of view, adopting this combination of supports can be very costly. It should be adopted when a high support capacity is indeed needed.

\section{Effect of space and size of steel arch support on mine tunnel stability}

As previously mentioned, the steel arch is the most appropriate support to be used in GDM underground coal mine for stabilizing the mine tunnel. The failure zone, especially in roof and sidewalls dramatically decreased, and the stability condition of the tunnel was improved considerably by the steel arch. In order to optimize the use of steel arch support, this section purposely studied the effect of row space and size of the steel arch on the stability of mine tunnel. Two row spaces $(0.5 \mathrm{~m}$ and $1 \mathrm{~m})$ and two sizes of cross section $(95 \times 115 \mathrm{~mm}$ and $105 \times 125 \mathrm{~mm}$ ) of the steel arch were investigated numerically. Table 6 summarizes the properties of steel arch used in the simulations in this section. 
International Journal of Engineering Applied Sciences and Technology, 2021

Vol. 6, Issue 4, ISSN No. 2455-2143, Pages 145-159

Published Online August 2021 in IJEAST (http://www.ijeast.com)

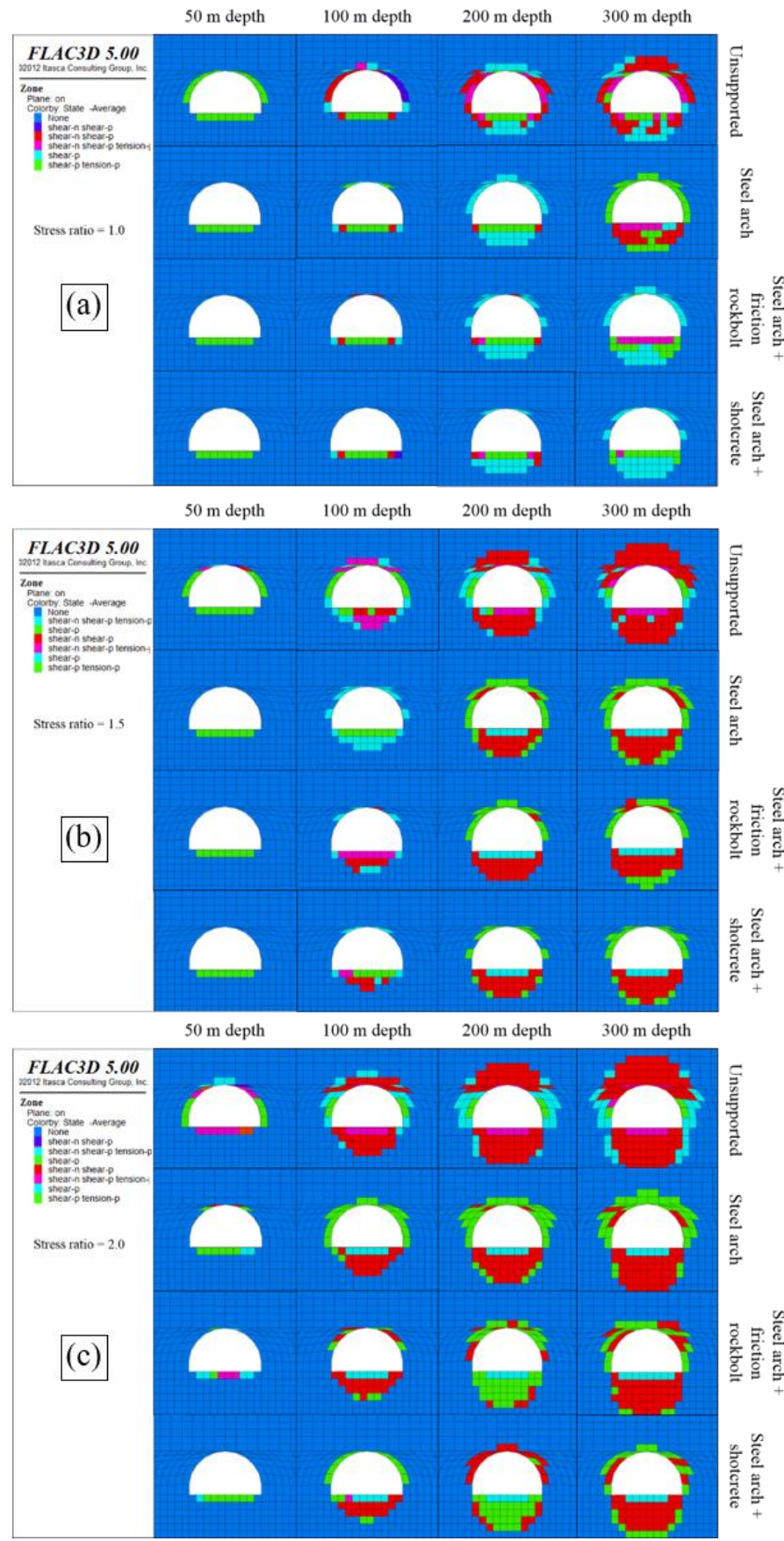

Fig. 14. Failure zone of tunnel after installation of steel arch, and steel arch in combination with friction rockbolt and shotcrete as auxiliary support (a) $\mathrm{k}=1.0$ (b) $\mathrm{k}=1.5$ (c) $\mathrm{k}=2.0$

According to the results presenting in Figure 15, a smaller failure zone could be observed when a closer space and a larger size of the steel arch were used. Decreasing the space from $1 \mathrm{~m}$ to $0.5 \mathrm{~m}$, and changing the size of the cross-section from $95 \times 115 \mathrm{~mm}$ to $105 \times 125 \mathrm{~mm}$ were effective to control the development of the failure zone. Therefore, it can be said that a better stability condition of the mine tunnel in the GDM underground coal mine can be achieved by decreasing the space and increasing the size of the steel arch.

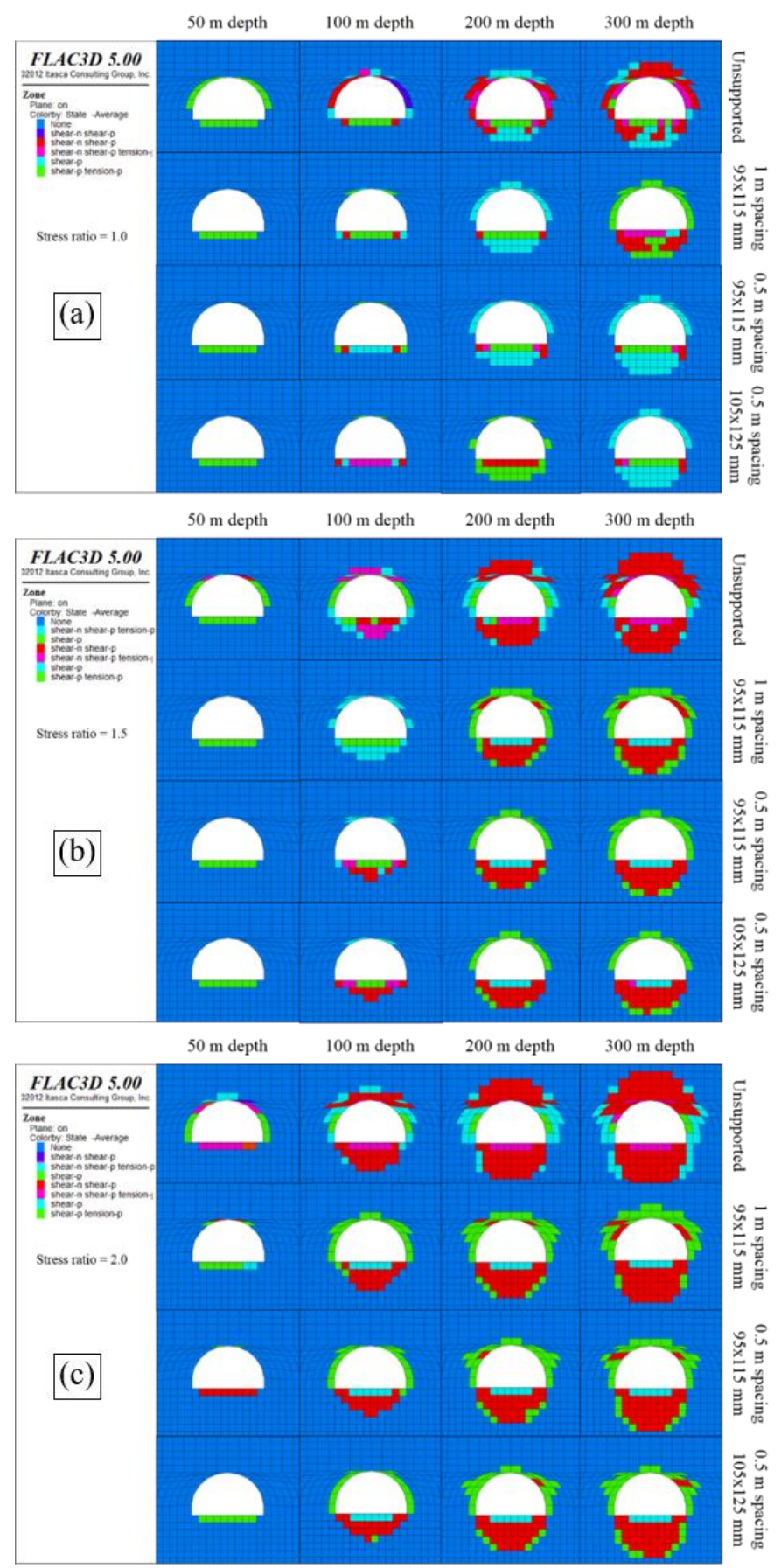

Fig. 15. Failure zone of mine tunnel after installation of steel arch with different spaces and sizes (a) $\mathrm{k}=1.0$ (b) $\mathrm{k}=1.5$ (c) $\mathrm{k}=2.0$ 


\section{International Journal of Engineering Applied Sciences and Technology, 2021 \\ Vol. 6, Issue 4, ISSN No. 2455-2143, Pages 145-159 \\ Published Online August 2021 in IJEAST (http://www.ijeast.com)}

Table -6 Comparison of mechanical properties of steel arch (JIS 3010) used in simulations

\begin{tabular}{|c|c|c|}
\hline Parameter & Value & Value \\
\hline Dimension $(\mathbf{m m})$ & $\mathbf{9 5 \times 1 1 5}$ & $\mathbf{1 0 5 \times 1 2 5}$ \\
\hline Cross section area $\left(\mathrm{cm}^{2}\right)$ & $\mathbf{3 6 . 5 1}$ & 44.19 \\
\hline Young's modulus $(\mathbf{G P a})$ & $\mathbf{2 0 0}$ & $\mathbf{2 0 0}$ \\
\hline Poisson's ratio & $\mathbf{0 . 3 0}$ & $\mathbf{0 . 3 0}$ \\
\hline Yield strength, SS540 $(\mathrm{MPa})$ & $\mathbf{5 5 1}$ & $\mathbf{5 5 1}$ \\
\hline
\end{tabular}

The results of steel arch axial stress in comparison with the maximum yield strength of steel arch SS540 are presented in Figure 16. It was clearly seen that a higher stress ratio generated a larger amount of steel arch axial stress. Reduction of the axial stress of the steel arch was significantly associated with decreasing the space and increasing the size of the steel arch. From this figure, under $\mathrm{k}=1$, it is suggested that the steel arch of $0.5 \mathrm{~m}$ space in both sizes of $95 \times 115 \mathrm{~mm}$ and $105 \times 125$ $\mathrm{mm}$ was adequate to stabilize the mine tunnel until $300 \mathrm{~m}$ depth. On the other hand, as k increased, the stability control of the tunnel at the deep area would be difficult even though the close space and the large size of steel arch were employed. According to the results of the $105 \times 125 \mathrm{~mm}$ size steel arch with $0.5 \mathrm{~m}$ space, the tunnel could be maintained only until 210 $\mathrm{m}$ and $165 \mathrm{~m}$ depth under $\mathrm{k}=1.5$ and 2 , respectively. It can be said that a higher capacity of support is needed in order to keep the tunnel stable until $300 \mathrm{~m}$ depth under $\mathrm{k}=1.5$ and 2 . For this reason, the use of a stronger steel arch, or the use of the steel arch in combination with other auxiliary supports such as rockbolt or/and shotcrete should be considered. However, it can cause some additional costs to this underground coal mine.
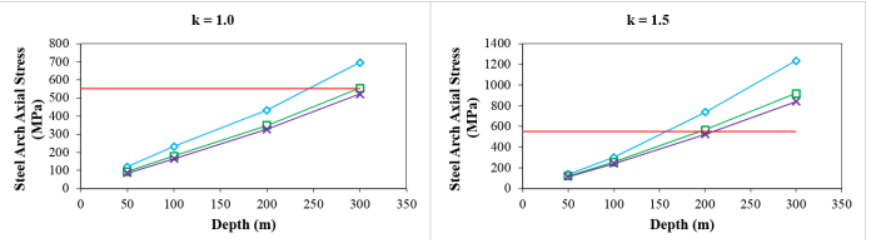

$k=2.0$

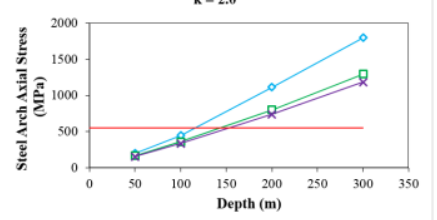

$\rightarrow-1 \mathrm{~m}$ spacing steel arch $(95 \times 115 \mathrm{~mm})$ $-0.5 \mathrm{~m}$ spacing steel arch $(95 \times 115 \mathrm{~mm})$ * $0.5 \mathrm{~m}$ spacing steel arch $(105 \times 125 \mathrm{~mm})$ - Maximum yield strength of steel arch, SS540

Fig. 16. Axial stress of steel arch support for tunnel under various overburden depths and stress ratios

\section{$D$. Support design of floor of mine tunnel}

According to simulation results presented in the previous sections, although the development of failure zone of the mine tunnel in roof and sidewalls could be controlled effectively by the steel arch support, the large failure and displacement still occurred in the floor due to the floor was left unsupported, especially when the excavation was conducted at a great depth and under high stress ratio. Figure 17 presents the failure condition and displacement of the floor at $300 \mathrm{~m}$ depth under various stress ratios. This large failure zone and displacement can lead to a severe floor heave unless an adequate support system is provided. Currently, the heaving of the tunnel floor at the GDM coal mine is recognized at the shallow depth, but it is not a serious issue, and easy to be overcome. Based on the simulation results, however, as the large failure and displacement of the floor are likely to occur at the deep area, a serious floor heave of the mine tunnel is expected. An appropriate design of the floor support is particularly important in this situation.
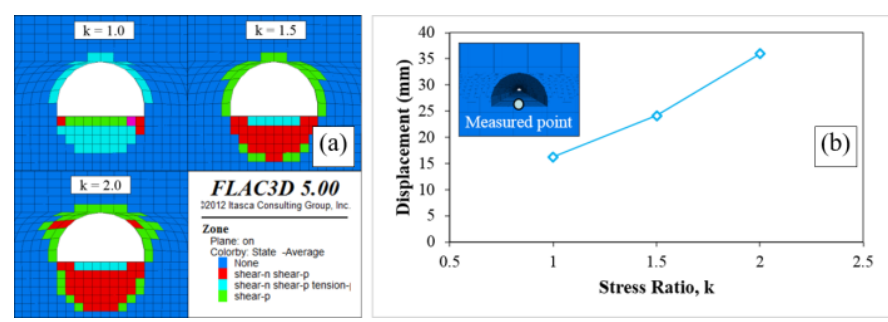

Fig. 17. Failure zone and displacement of unsupported floor of mine tunnel at $300 \mathrm{~m}$ depth

At present, several techniques have been used in order to control the floor stability of mine tunnels, such as digging method, grouting, rockbolt, cablebolt, invert-arch floor, and grooving method. Excavating the heaved floor using a digging machine can be the cheapest method of control, but it can cause a reduction of coal productivity due to the delay as it needs time to clean the heaved floor. Floor grouting can be the most effective method to control the floor heave. The grouting materials enhance the strength of surrounding rocks by sealing and connecting the fractures within the rock mass. However, it is considered the most expensive method among the others. Controlling the floor heave using rockbolt or cablebolt, or the combination of these supports has been implemented successfully in an underground mine for many years. Rockbolt or cablebolt is beneficial to strengthen the rock mass and to restrict the development of rock failure and displacement. The use of these supports becomes popular currently because of not only their inexpensiveness, but also they have simple processes of installation. Using an invert-arch floor aims at restricting the heaving of the tunnel floor. The heave of the tunnel floor is strongly restrained by the great stiffness of the arch. The invertarch floor is normally supported by concrete [17]. The stress distribution in the rock mass surrounding the floor can be improved by adopting the invert-arch floor. It can decrease the high stress concentrations at the corners where the sidewalls meet the invert floor. The invert-arch floor provides a smooth path of stress distribution around the floor, and as a result, the floor heave can be minimized [14]. Grooving method is an alternative floor heave control. It is particular to control the floor heave under high horizontal stress conditions. Compared with other supporting methods such as rockbolt, cablebolt, etc., 


\section{International Journal of Engineering Applied Sciences and Technology, 2021 \\ Vol. 6, Issue 4, ISSN No. 2455-2143, Pages 145-159 \\ Published Online August 2021 in IJEAST (http://www.ijeast.com)}

grooving method has a different mechanism for floor heave control. It changes the stress state of surrounding rocks. Particularly, it makes the floor strata in the stress reduction zone by transferring the maximum stress to the deep rocks and promotes the stress-relief effect $[18,19]$.

In order to prevent the floor heave that may occur due to the large displacement and failure, three techniques of control including the application of cablebolt, invert-arch floor, and grooving method were assessed and discussed in this paper. A case of $300 \mathrm{~m}$ deep tunnel under various stress ratios was simulated numerically.

\section{D.1. Floor heave control by cablebolt support}

As a rule, to use the cablebolt for controlling the floor heave, the thickness of the failure zone indicates the length of cablebolt required, and the minimal length has to be longer than the thickness of the failure zone. According to Figure 17.a, the largest failure zone of $3 \mathrm{~m}$ in thickness occurred in a case of $\mathrm{k}$ equals 2 . Therefore, the minimal length of cablebolt has to be longer than $3 \mathrm{~m}$. To simulate the effects of cablebolt on the reduction of failure zone and displacement, three cablebolt lengths of $3.5 \mathrm{~m}, 4 \mathrm{~m}$, and $4.5 \mathrm{~m}$, and two row spaces of $1 \mathrm{~m}$ and $0.5 \mathrm{~m}$ were investigated. The pattern of support system is presented in Figure 18. The support system includes a $0.5 \mathrm{~m}$ spaced steel arch of $95 \times 115 \mathrm{~mm}$ size in roof and sidewalls, and six fully grouted cablebolts in the floor. The properties of cablebolt used in the analysis are provided in Table 7.

Table -7 Mechanical properties of cablebolt used in simulations

\begin{tabular}{|c|c|}
\hline Parameter & Value \\
\hline Diameter (mm) & 19 \\
\hline Typical tensile strength (kN) & 548 \\
\hline Young's modulus (GPa) & 200 \\
\hline Grout compressive strength (MPa) & 20 \\
\hline Grout cohesion (MPa) & 10 \\
\hline Grout friction angle $\left(^{\circ}\right)$ & 30 \\
\hline
\end{tabular}

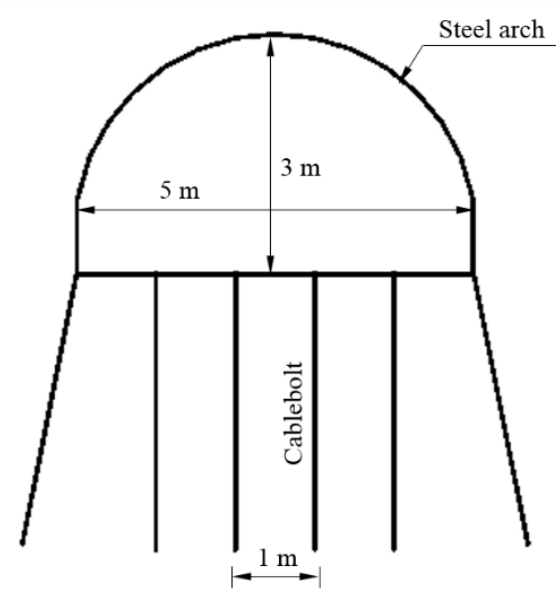

Fig. 18. Support pattern of mine tunnel for floor stability analysis using cablebolt
The influence of the row space of cablebolt on the floor stability was firstly analyzed and discussed. Figure 19 shows the results of failure zone and displacement after the floor was supported by cablebolts with two different row spaces of $1 \mathrm{~m}$ and $0.5 \mathrm{~m}$. The length of cablebolt was kept constant at $3.5 \mathrm{~m}$ in the case. Compared with the unsupported floor, the floor condition considerably improved as the failure zone and displacement decreased under all stress ratios. This proves that the cablebolt support worked efficiently to control the floor heave problem. The floor which was supported by a closer row spaced cablebolt produced a smaller failure zone and displacement amount. This indicates that a better floor condition could be obtained by reducing the row space of cablebolt. Furthermore, the results also indicate that the floor displacement under high stress ratio decreased significantly. It was reduced by approximately $60 \%$ of the maximum floor displacement when $\mathrm{k}=2$. This reveals that the floor stability of the tunnel in the GDM coal mine under high stress ratio could be controlled effectively by the cablebolt support.
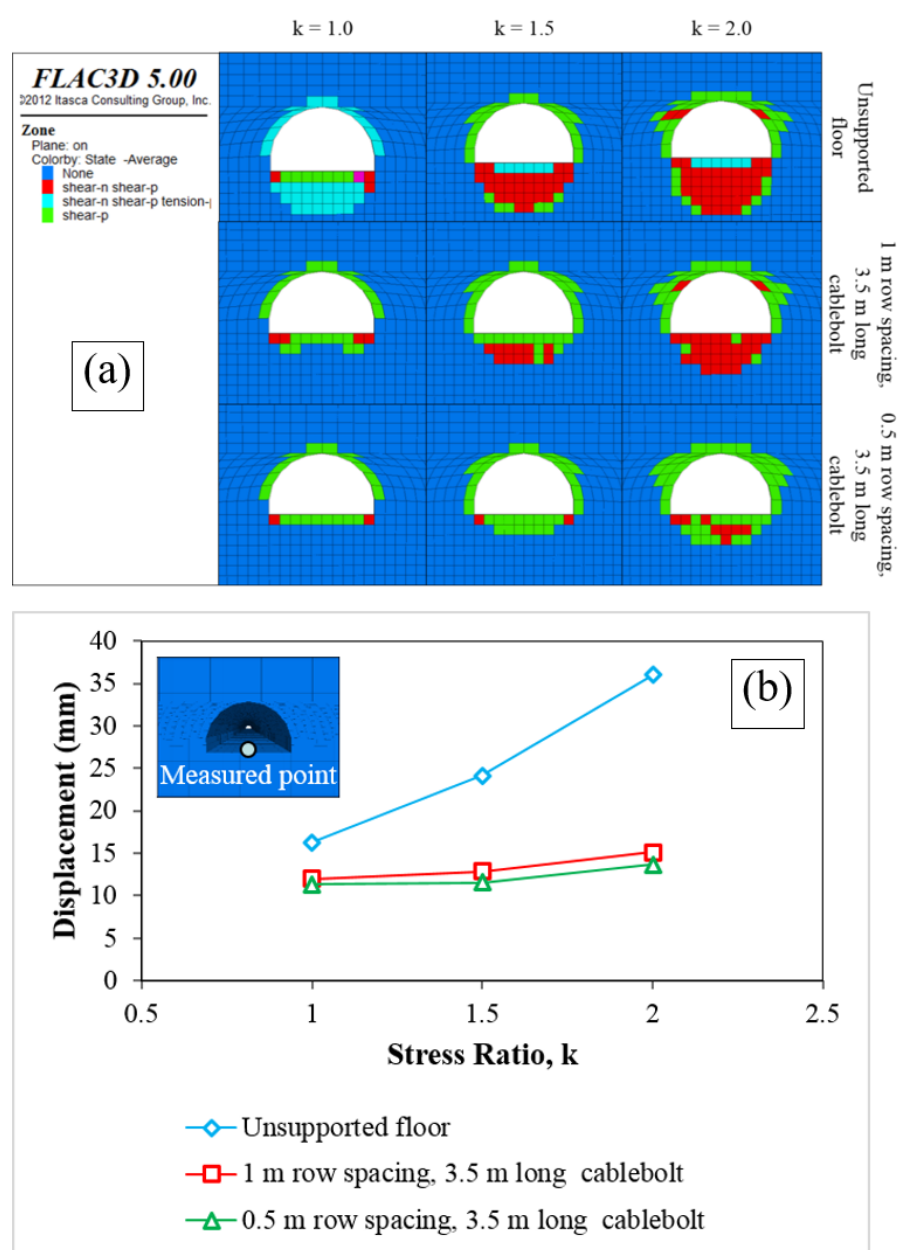

Fig. 19. (a) Failure zone and (b) Displacement of supported floor of mine tunnel at $300 \mathrm{~m}$ depth under different row spaces of cablebolt 


\section{International Journal of Engineering Applied Sciences and Technology, 2021 \\ Vol. 6, Issue 4, ISSN No. 2455-2143, Pages 145-159 \\ Published Online August 2021 in IJEAST (http://www.ijeast.com)}

The effect of the length of cablebolt on the floor stability was secondly studied. Three lengths of $3.5 \mathrm{~m}, 4 \mathrm{~m}$, and $4.5 \mathrm{~m}$ were simulated, and the row space was fixed at $0.5 \mathrm{~m}$ throughout the analyses. The results of failure zone and displacement are demonstrated in Figure 20. From the failure zone results, no reduction of the floor failure was observed even though the long cablebolt of $4.5 \mathrm{~m}$ was applied. The floor failure under all cases of stress ratios remained the same as the cablebolt length increased. It can be said that increasing the length of cablebolt does not influence the reduction of floor failure. The cablebolt of $3.5 \mathrm{~m}$ length will be sufficient to restrict the failure development of the floor. However, based on the displacement results, the floor displacement reduced when the length of cablebolt increased from $3.5 \mathrm{~m}$ to $4 \mathrm{~m}$. After that, the displacement remained almost stable although the length increased to $4.5 \mathrm{~m}$. Thus, it can be confirmed that the cablebolt with a length over $4 \mathrm{~m}$ will not provide a significant improvement of the floor stability. Over-design of the length will only lead to unnecessary additional costs. An appropriate length must be designed carefully on the basis that an adequate length of cablebolt has to be longer than that the thickness of the failure zone so that they can be anchored in an undamaged floor region.
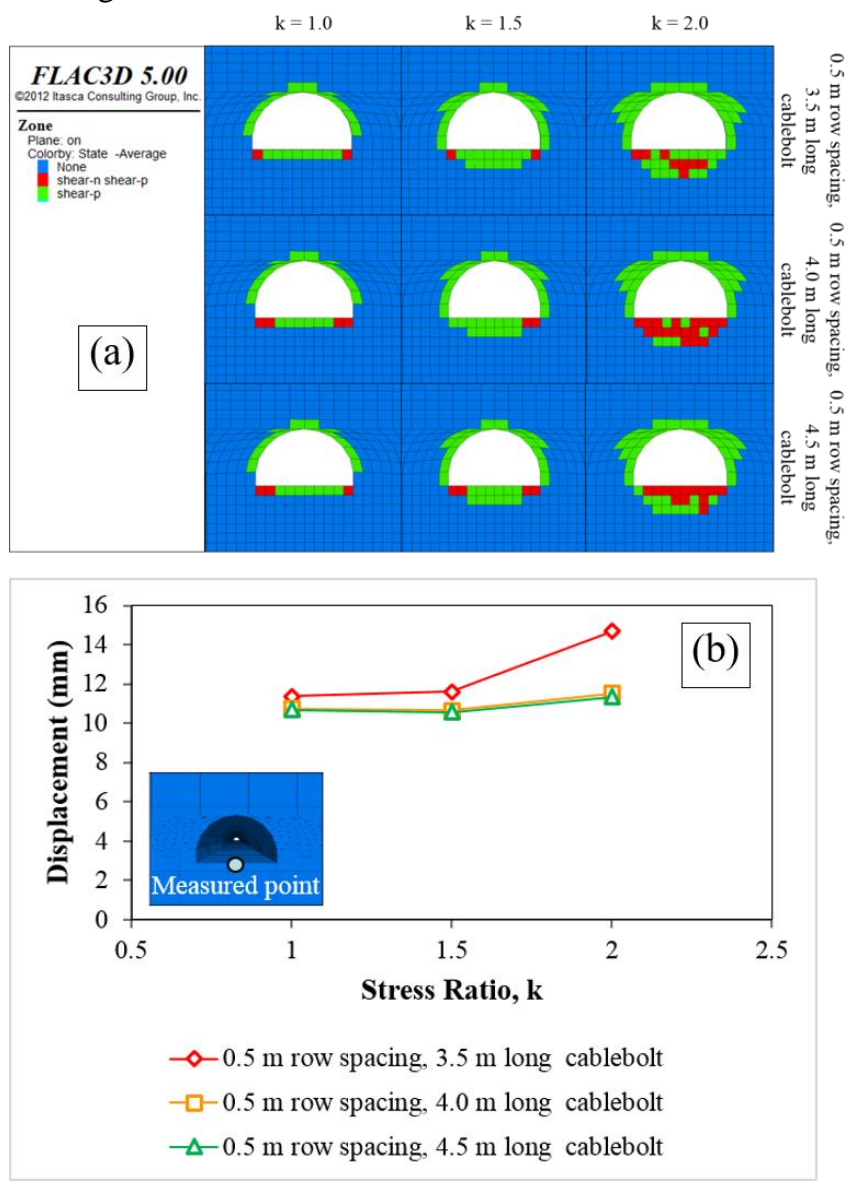

Fig. 20. (a) Failure zone and (b) Displacement of supported floor of mine tunnel at $300 \mathrm{~m}$ depth under different lengths of cablebolt

\section{D.2. Floor heave control by invert-arch floor method}

In order to control the floor heave by an invert-arch floor method, the invert-arch was constructed on the floor. After the invert-arch floor was constructed, the shotcrete of $10 \mathrm{~cm}$ in thickness was applied to the floor surface. Figure 21 shows the support pattern of the mine tunnel. The tunnel was supported by $0.5 \mathrm{~m}$ spaced steel arches $(95 \times 115 \mathrm{~mm})$ in the roof and sidewalls, and the shotcrete in the floor. To investigate the effect of the invert-arch depth, three depths of the invert-arch were simulated, such as $0.5 \mathrm{~m}, 1 \mathrm{~m}$, and $1.5 \mathrm{~m}$.
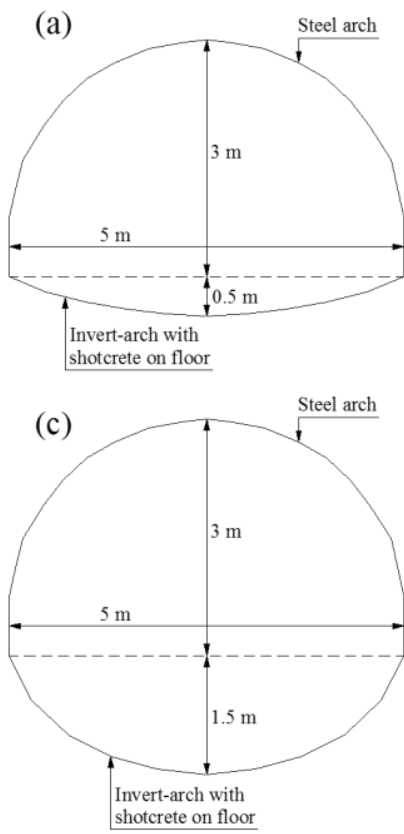

Fig. 21. Support pattern of mine tunnel for floor stability analysis using invert-arch floor method (a) $0.5 \mathrm{~m}$ deep invert-arch (b) $1 \mathrm{~m}$ deep invert-arch (c) $1.5 \mathrm{~m}$ invert-arch

Figure 22 illustrates the failure zone and displacement of the floor of the mine tunnel under different invert-arch depths. Compared with the unsupported floor without invert-arch, the failure zone and displacement decreased significantly, especially when the mine tunnel was excavated under high stress ratio. From the figure, it was clearly seen that the flat floor of the mine tunnel allowed more heaving of the floor. High concentrations of the stress were created on the sharp corners at the junction between the floor and the tunnel sidewalls of the mine tunnel. Failure of the floor was generally initiated at these corners. In contrast, the failure zone and heaving of the floor were reduced considerably by the presence of the invert-arch in the floor. The invert-arch provided the surrounding rocks with a smooth stress distribution around the floor, and it helped to reduce the stress concentrations at the corners. At the same time, the shotcrete on the floor increased 


\section{International Journal of Engineering Applied Sciences and Technology, 2021 \\ Vol. 6, Issue 4, ISSN No. 2455-2143, Pages 145-159 \\ Published Online August 2021 in IJEAST (http://www.ijeast.com)}

the strength of the floor surface, and it also helped to resist the stresses imposed on the floor. As a result, the smaller failure zone and displacement were generated.

Furthermore, the simulated results also reveal that an increase in the invert-arch depth was very effective to minimize the failure zone and displacement of the floor. The existence of a deeper invert-arch in the floor produced a smaller failure zone and displacement. This happens because the invert-arch with a deeper depth created less stress concentrations at the corners, and it promoted a smoother stress distribution around the floor rocks. For example under $\mathrm{k}=2$, compared with the floor with no invert-arch, $0.5 \mathrm{~m}$ deep invert-arch, and $1 \mathrm{~m}$ deep invert-arch, the displacement of the floor with $1.5 \mathrm{~m}$ deep invert-arch decreased considerably from $36 \mathrm{~mm}, 19.28 \mathrm{~mm}$, and $11.59 \mathrm{~mm}$ to $8.38 \mathrm{~mm}$, respectively. Based on the simulated results discussed above, it can be said that the invertarch floor method is very effective to control the floor heave problem. A better floor stability condition can be achieved by constructing a deeper invert-arch in the floor. However, even though the method works effectively for controlling the floor heave, since the mine tunnel with the invert-arch floor will not give a wide flat floor, it decreases the working space and may limit the size and shape of the equipment used during the construction and production of the mine
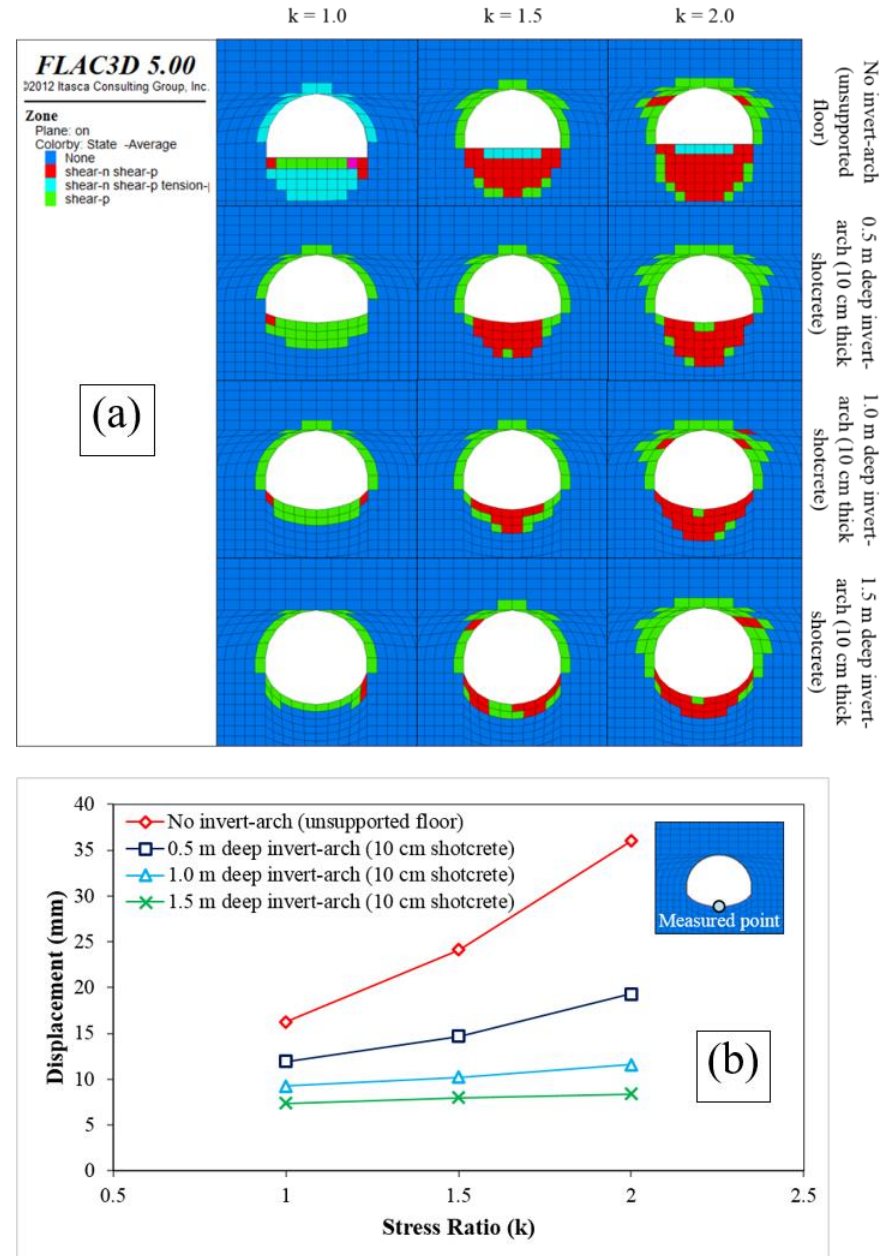

Fig. 22. (a) Failure zone and (b) Displacement of supported floor of mine tunnel at $300 \mathrm{~m}$ depth under different depths of invert-arch

\section{$D .2$. Floor heave control by grooving method}

In order to study the floor heave control by grooving method, a $1 \mathrm{~m}$ wide crevice was excavated in the middle of the floor. Four crevice depths of $0.5 \mathrm{~m}, 1 \mathrm{~m}, 1.5 \mathrm{~m}$, and $2 \mathrm{~m}$ were simulated to investigate the effect of the crevice depth. The tunnel was supported by $0.5 \mathrm{~m}$ spaced steel arches $(95 \times 115$ $\mathrm{mm}$ ) in the roof and sidewalls throughout the simulations (Fig. 23). 

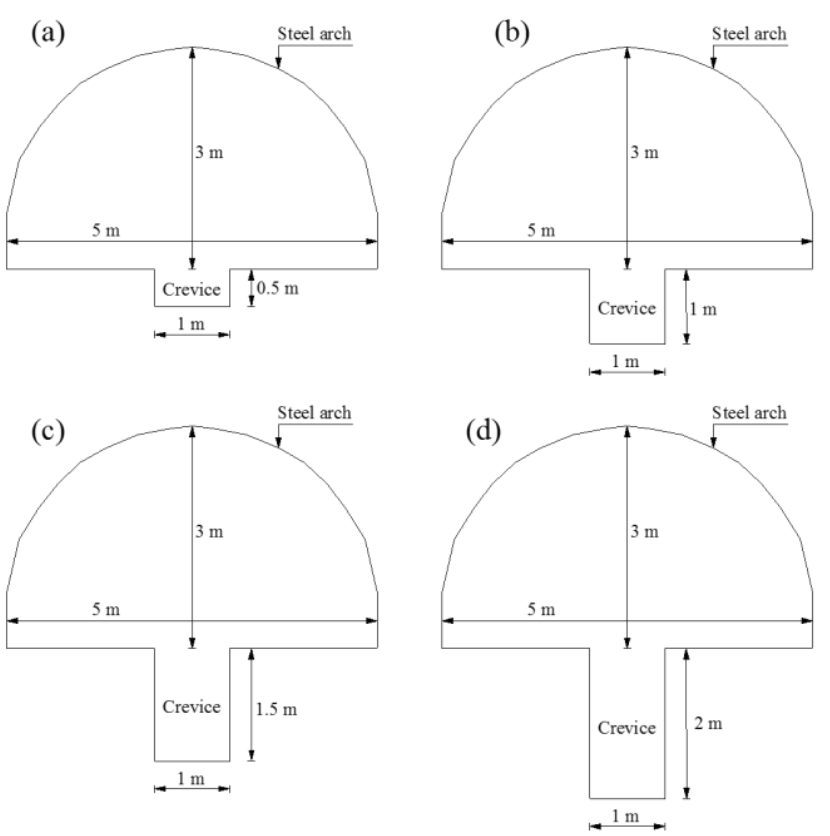

Fig. 23. Support pattern of mine tunnel for floor stability analysis using grooving method (a) $0.5 \mathrm{~m}$ deep crevice (b) $1 \mathrm{~m}$ deep crevice

(c) $1.5 \mathrm{~m}$ deep crevice (d) $2 \mathrm{~m}$ deep crevice

Figure 24 demonstrates the horizontal stress distribution below the floor corners of the tunnel under various crevice depths. The horizontal stress in the range of $5 \mathrm{~m}$ below the floor corners was monitored. The simulated results show that the presence of the crevice promoted the stress-relief effect. The relief of floor stress is significantly favorable to control the floor heave. The horizontal stress close to the floor corners dropped gradually with the existing crevice. Without the crevice, the direct floor is in a high stress state. As the crevice depth increased, the effect of stress transfer was noticeable, the stress of the floor was continuously reduced by transferring to the deep rocks. The deepest crevice depth of $2 \mathrm{~m}$ showed the best depth of the crevice since it produced the smallest direct floor stress and transferred the peak stress to the deepest rocks. This means that the floor heave can be more effectively controlled by increasing the crevice depth. Compared the results, grooving method worked more effectively to control the floor heave under a higher stress ratio. Under a higher stress ratio, the peak stress was transferred to a deeper area below the floor corners. This indicates that the grooving method is appropriate to be adopted when the tunnel is excavated in the area where the horizontal stress is larger than the vertical stress.
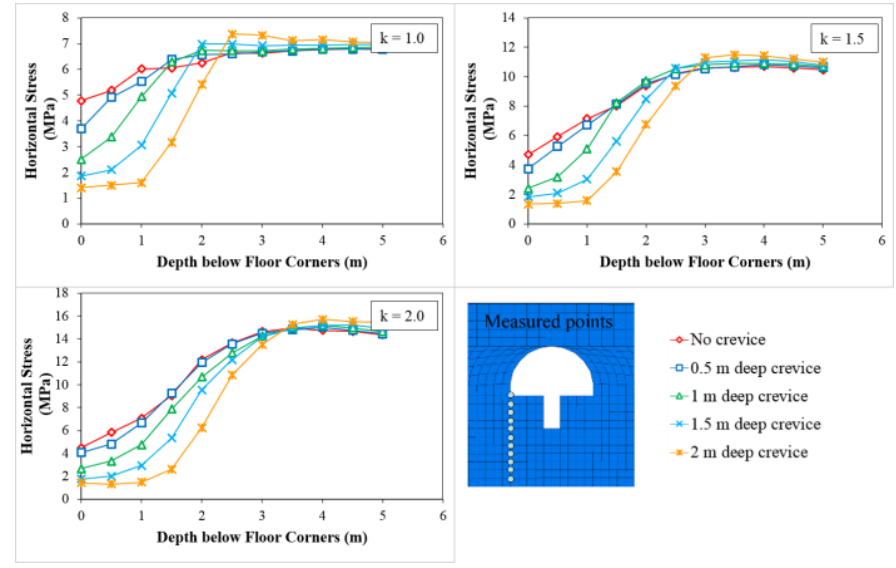

Fig. 24. Relationship between crevice depth and horizontal stress below floor corners of mine tunnel at $300 \mathrm{~m}$ depth

Figure 25 illustrates the displacement vectors of the mine tunnel. It can be seen that the grooving method provided surrounding rocks with a deformation space. It modified the direction of floor movement. The floor moved toward the crevice room which moderated the extrusion deformation of the floor, resulted in a reduction of the floor heave. The tunnel with a deeper crevice generated a smaller floor heave as the floor moved more horizontally toward the crevice space. In addition, the displacement vector results support the results of horizontal stress distribution. Grooving method controlled the floor heave more effectively under a higher stress ratio. The more horizontal movement of the floor was observed when the tunnel was excavated under a higher stress ratio. However, although this method is effective to control the floor heave problem, since the crevice is excavated in the middle of the floor, it may cause the accident during the transportation of miners, equipment, and coal. The risk of the accident can be reduced by constructing the crevice at the floor corners or backfilling the crevice with the appropriate materials that can restrict the closing trend and making full use of the effects achieved by grooving.

Although the three methods of cablebolt support, invertarch floor, and grooving methods are effective to control the floor heave problem, controlling the floor heave by cablebolt support can be considered as the most appropriate technique in GDM underground coal mine. The cablebolt is simple to be installed, and it remains the floor flat and wide in an original shape. Unlike the invert-arch floor and grooving methods, the floor has to be excavated in order to form the invert-arch and crevice in the floor. These methods change the floor shape and decrease the working space of the floor. The grooving method also tends to decrease the safe working conditions since the crevice is constructed in the middle of the floor. In addition, the shotcrete which is applied on the floor surface for the invertarch method needs time for achieving the desired strength. Additionally, the installation price in $1 \mathrm{~m}$ length of the shotcrete (2368 USD) is much higher than that of the cablebolt 
(540 USD) [16]. This makes the floor heave control by the invert-arch floor method is more expensive than the cablebolt support.

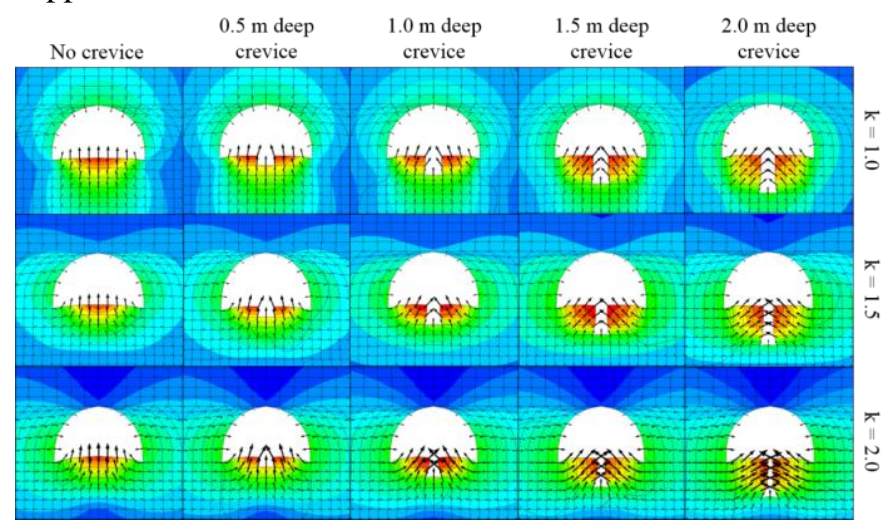

Fig. 25. Displacement vectors of mine tunnel with existence of crevice in floor at $300 \mathrm{~m}$ depth

\section{CONCLUSION}

The stability of the mine tunnel under various overburden depths and stress ratios with different support systems is studied by means of numerical simulations using finite difference code software, FLAC3D. Based on the results, it is found that the overburden depth and stress ratio significantly influence tunnel stability. The thickness of the failure zone increases with increasing the overburden depth and stress ratio. The tunnel which is excavated at a deeper depth and under a greater stress ratio experiences a larger failure zone and needs a higher capacity of support. The use of friction rockbolt, steel arch, and shotcrete as the support system for roof and sidewalls is investigated. The steel arch is considered as the most appropriate support to be used as the main support system for the roof and sidewalls comparing with the others. It meets the qualifications of stability control, a fast installation process, and economy. The steel arch significantly improves the stability condition of the roof and sidewalls, and the failure zone decreases considerably after the steel arch is applied. In addition, the use of friction rockbolt and shotcrete as auxiliary support is also investigated. Compared with the tunnel supported by steel arch only, the failure zone decreases apparently.

As the steel arch is the most appropriate support to be used as the main support system for roof and sidewalls, to optimize the use of steel arch, the effect of space and size of the steel arch on the mine tunnel stability is investigated. It is found that the steel arch with closer space and larger size gives a better stability condition. Based on the results of steel arch axial stress, under $\mathrm{k}=1$, it suggests that the steel arch SS540 of $0.5 \mathrm{~m}$ space in both the sizes of $95 \times 115 \mathrm{~mm}$ and $105 \times 125 \mathrm{~mm}$ is adequate to stabilize the tunnel until $300 \mathrm{~m}$ depth. On the other hand, as $\mathrm{k}$ increases, the stability control of the mine tunnel in the roof and sidewalls at the deep area will be difficult even though the close space and the large size of steel arch are employed. According to the results of the $105 \times 125 \mathrm{~mm}$ size steel arch with $0.5 \mathrm{~m}$ space, the roof and sidewalls of the mine tunnel can be maintained only until $210 \mathrm{~m}$ and $165 \mathrm{~m}$ depth under $\mathrm{k}=1.5$ and 2 , respectively. For this reason, the use of a stronger steel arch, or together with rockbolt or shotcrete is recommended when the tunnel is excavated under a high stress ratio and at a great depth.

Although the roof and sidewalls of the mine tunnel are well controlled by steel arch support, the large floor failure and displacement still occur, especially when the tunnel is excavated at a great depth and under a high stress ratio. The floor heave problem can be expected if no appropriate control measure is provided. The use of cablebolt is firstly investigated for stability control of the floor. It works effectively to restrain the failure zone and displacement, especially under high stress ratio. About $60 \%$ of the maximum floor displacement is reduced under $\mathrm{k}=2$. Row space of cablebolt has a significant influence on the floor stability. A closer row space provides a smaller floor failure and displacement. Furthermore, the floor is also supported with different lengths of cablebolt. Increasing the length from $3.5 \mathrm{~m}$ to $4 \mathrm{~m}$ and $4.5 \mathrm{~m}$ does not reduce the thickness of failure zone. This reveals that a cablebolt of $3.5 \mathrm{~m}$ length will be sufficient to restrain the development of floor failure. However, the decrement of floor displacement is observed when the length of cablebolt increases.

The invert-arch floor method is secondly investigated for floor heave control. The method is very effective to reduce the heaving of the floor, especially under a high stress ratio. The floor failure and displacement significantly decrease with presence of the invert-arch in the floor. The invert-arch reduces the stress concentrations at the corners where the sidewalls meet the floor, and it provides the surrounding rocks with a smooth stress distribution around the floor. At the same time, the shotcrete applied on the floor increases the floor strength, and resists to the stresses imposed on the floor. Consequently, the failure zone and displacement decrease. In addition, by increasing the depth of the invert-arch, more failure zone and displacement can be reduced. A deeper invert-arch creates less stress concentrations at the floor corners, and provides a smoother stress distribution around the floor rocks. As a result, a smaller failure zone and displacement occur in the floor.

Controlling the floor heave by grooving method is lastly investigated. The method promotes the stress-relief effect of the floor, which helps to minimize the floor heave amount. An increase in crevice depth induces the relief of floor stress by transferring the peak stress to the deep rocks, so that the floor heave can be more effectively controlled. Grooving method provides the surrounding rocks with a deformation space. It modifies the movement direction of the floor. The floor moves toward the crevice space, and the floor heave can be minimized. Increasing the crevice depth enlarges the deformation space, as a result, the floor heave can be more effectively minimized. The simulated results indicate that the use of grooving method is more appropriate when the tunnel is 


\section{International Journal of Engineering Applied Sciences and Technology, 2021 \\ Vol. 6, Issue 4, ISSN No. 2455-2143, Pages 145-159 \\ Published Online August 2021 in IJEAST (http://www.ijeast.com)}

excavated under a higher stress ratio. Under a higher stress ratio, the peak stress is transferred to a deeper area, and more horizontal movement of the floor is observed.

Although the heaving of the floor can be controlled effectively by the cablebolt, invert-arch floor, and grooving methods, controlling the floor heave by cablebolt support can be the most appropriate technique in GDM coal mine comparing with other methods in terms of the installation process, providing a flat and safe working condition of floor, and economy.

\section{REFERENCE}

[1] Indonesia-Investments, Available: http://www.indonesiainvestments.com/. [Accessed: July, 2021]

[2] Matsui K., Shimada H., Furukawa H., Kramadibrata S., and Anwar H.Z. (2003). Ground control problems and roadheader drivage at Ombilin coal mine, Indonesia. Proceeding of the $18^{\text {th }}$ International Mining Congress and Exhibition of Turkey-IMCET, (pp. 99-104).

[3] Sasaoka T., Shimada H., Ichinose M., Matsui K., Kramadibrata S., Sulistianto B., and Watinena R. (2007). Improvement in roof support system at a new underground coal mine developed from open-cut highwall in Indonesia. Proceeding of the $26^{\text {th }}$ International Conference on Ground Control in Mining, (pp. 122- 128).

[4] Sasaoka T., Shimada H., Zarlin N., Takamoto H., Matsui K., Kramadibrata S., and Sulistianto B. (2014). Geotechnical issues in the application of rock bolting technology for the development of underground coal mines in Indonesia. International Journal of Mining, Reclamation and Environment, vol. 28, no. 3, (pp. 150172).

[5] Takamoto H., Sasaoka T., Shimada H., Oya J., Hamanaka A., and Matsui K. (2014). Study on surface subsidence due to longwall mining operation under weak geological condition in Indonesia. ICGCM China Proceedings, (pp. 177-182).

[6] Sasaoka T., Takamoto H., Shimada H., Oya J., Hamanaka A., and Matsui K. (2015) Surface subsidence due to underground mining operation under weak geological in Indonesia. International Journal of Rock Mechanics and Geotechnical Engineering, vol. 7, no. 3, (pp. 337-344).

[7] Sasaoka T., Shimada H., Hamanaka A., Sulistianto B., Ichinose M., and Matsui K. (2015). Geotechnical issues on application of highwall mining system in Indonesia. Vietrock 2015 an ISRM Specialed Conference.

[8] Bieniawski Z. T. (1974). Estimating the strength of rock masterials. International Journal of the South African Institute of Mining and Metallurgy, vol. 74, no. 8, (pp. 312-320).

[9] Hoek E., and Brown E. T. (1997). Practical estimates of rock mass strength. International Journal of Rock
Mechanics and Mining Sciences, vol. 34, no. 8, (pp. 1165-1186).

[10] Garcia A., Altounyan P., Nitaramorn A., and Lewis A. (2010). Ground control aspects of a successful underground coal mine trial in weak strata in Indonesia. Proceeding of the $29^{\text {th }}$ International Conference on Ground Control in Mining.

[11] Itasca Consulting Group, Inc. (2009). FLAC3D Fast Lagrangian Analysis of Continua in 3 Dimensions: User's Guide. Mill Place, Minneapolis, 55401 USA.

[12] Hoek, E., and Brown, E. T. (1980). Underground excavations in rock. London, UK.

[13] Hoek, E., and Wood, D. F. (1987). Support in underground hard rock mines. Underground Support Systems, 35, (pp. 1-6).

[14] Hoek, E., Kaiser, P. K., and Bawden, W. F. (1993). Support of underground excavations in hard rock. West Btunnel Professional Centre, Vancouver, British Columbia.

[15] Hoek, E. (2006). Practice rock engineering. North Vancouver, B. C., Canada V7R 4X1.

[16] Tri K. (2016). Stability Control Measures for Crown Pillar in Cut and Fill Underground Gold Mine under Protected Forest Area, Indonesia. Thesis (PhD), Kyushu University, Japan.

[17] Hudson, J., Brown, E. T., Fairhurst, C., and Hoek, E. (2016). Comprehensive rock engineering volume 4: Excavation, support and monitoring. Imperial College of Science, Tecnology \& Medicine, London, UK: Pergamon Press.

[18] Jin, S., and Lianguo, W. (2011). Numerical simulation of grooving method for floor heave control in soft rock tunnel. International Journal of Mining Science and Technology (China), 21, (pp. 49-56).

[19] Liu, C., Ren, J., Zhang, K., and Chen, S. (2017). Numerical study on surrounding rock deformation controlled by pressure relief groove in deep tunnel. International Symposium on Resource Exploration and Environmental Science, 64, (pp. 1-9). 